\title{
Effect of Work Motivation, and Compensation on Employee Performance through Job Satisfaction at STIE Kertanegara Malang of Indonesia
}

\author{
Suprihatiningsih, Tanto Gatot, Sunardi, and Dyah Setyawati \\ University of Merdeka Malang, Indonesia
}

\begin{abstract}
This study aims to explain the influence of motivation and compensation on employee job satisfaction, explain the influence of motivation, compensation, and job satisfaction on employee performance, and explain the influence of motivation and compensation through job satisfaction on employee performance at STIE Kertanegara Malang. The number of samples considered in this study was 30 employees. The analysis technique uses path analysis. The results of the analysis show that motivation and compensation have an effect on job satisfaction. Motivation, compensation, and job satisfaction affect employee performance. Motivation and compensation affect employee performance through job satisfaction.
\end{abstract}

Keywords: Motivation, Compensation, Job Satisfaction, Employee Performance.

\section{INTRODUCTION}

In the current era, an organization or company is required to be able to manage human resources who are competent and have high morale in order to balance the intense competition in the era of globalization. How well the resources managed by the organization or company will determine the success of the company in the future. The management of human resources itself means that an organization or company must be able to unite the mindset and perspective of leaders and employees in achieving organizational goals through the formation of a good work mentality and with dedication, high loyalty to their work, providing work motivation, direction, and good coordination. in working by a leader to his subordinates, and this becomes an important part of the company's management duties. In principle, human resources are one of the keys that determines the company, to be able to achieve the goals of a good company or organization not only with the facilities and infrastructure owned, but without the presence of human resources, it is likely that the organization or company will find it difficult to achieve its intended goals. To develop their business, this human resource factor is an element that must be considered by every organization or company, especially in the current era of globalization, where the competition faced will be very different. This will force an organization to work more productively. To get the expected human resources in achieving organizational or company goals, there are many ways that must be done, including giving good motivation to human resources. Every organization certainly has goals to be achieved, these goals will be achieved by using existing resources.

STIE Kertanegara Malang is an organization that is engaged in education, namely the Foundation for the College of Economics where the organization is required to be able to provide the best service to the public (students). STIE Kertanegara Malang has been widely known among the community, especially in the surrounding community who want to continue education in the economic field. It cannot be denied that human resources at STIE Kertanegara Malang have decreased in performance in providing services to the community. The efforts made to improve the performance of these employees it can be done by providing work motivation, compensation and job satisfaction. Motivation is the key to the success of an organization,

Work motivation, compensation and job satisfaction is one of the factors that will affect the performance of employees in STIE Kertanegara Malang. With work motivation, employees will be able to carry out the tasks assigned by the company to them and this will have an impact on the performance of existing employees. As previously mentioned, motivation has, namely motivation to be a motivation for someone to work. The importance of motivation is a cause and support for human behavior, so that they are willing to work hard and enthusiastically to achieve optimal results. According to Sopiah (2008: 170) argues that " motivation is a condition in which the effort and willpower of a person is directed towards the achievement of certain results or goals. Compensation is a meaningful aspect for employees, because if the compensation is given correctly to employees, in this 
case the employees will be motivated and more focused on achieving goals in an organization. Furthermore, Rivai (2004: 357) argues that compensation is the main cost of expertise or work and loyalty in business in companies in the 21 st century.

In an organization expecting a success, to achieve these goals it requires quality employees. To create quality employees, a strong encouragement is needed besides motivation and compensation, namely job satisfaction. Employees or employees will feel satisfied at work if aspects of the job and aspects of themselves support and vice versa if these aspects do not support, then the employee or employees will feel dissatisfied at work. Job satisfaction is one very important factor also for employees in completing tasks that have been given by the organization or company. Mangkunegara (2016: 117) job satisfaction is a feeling that supports or does not experienced by employees at work. Employee performance is basically what employees do and what they don't do so that they influence how much they contribute to the agency or organization including the quality service provided.

\section{LITERATURE REVIEW}

\subsection{Performance}

Performance is a result of work produced by an employee, in this case it can be interpreted that performance is to achieve the expected goals. Mangkunegara (2016: 67) Performance comes from the word Job Performance which means work performance or actual achievement achieved by someone. The definition of performance (work performance) is the work result in quality and quantity achieved by an employee in carrying out his function in accordance with the responsibilities given to him. As for some experts, the opinion regarding performance is as follows:

According to Wibowo $(2010 ; 7)$ suggests that performance is about doing work and the results achieved from that work, while according to Notoatmodjo (2009: 124) suggests that: Performance is what a person does in accordance with their duties and functions. In this case, based on several experts, it can be concluded that performance is a result achieved by an employee in accordance with the standards and criteria that have been set within a certain period of time.

According to Mangkunegara (2016: 75) states that the performance indicators are as follows: 1) Quality, work quality is how well an employee does the task that should be done, 2) Quantity, work quantity is how long an employee can complete his task in one day. In this work quantity can be seen from the work speed of each employee respectively. 3) Implementation of duties, the implementation of tasks is how far the employee is able to do his job accurately or without errors and 4) Responsibility, responsibility for work is the awareness of the employee's obligation to carry out the work given by the company.

\subsection{Job Satisfaction}

Robbin (2003: 78) job satisfaction is a general attitude towards a person's job which shows the difference between the amount of rewards that workers receive and the amount they believe they should receive. Greenberg and Baron (2003: 78) describe job satisfaction as positive or negative by individuals on their work. In addition, according to Gibson (2000: 106), job satisfaction is an attitude that workers have about their work.

As for the indicators of job satisfaction, Hasibuan (2001: 202) states that job satisfaction indicators include: 1) Loyalty, the assessment measures the loyalty of employees to their jobs, positions and organizations. This loyalty is reflected in the willingness of employees to maintain and defend the organization inside and outside of work. . 2) Ability, assessors Assess the work results both quality and quantity that can be generated by the employee from the job description. 3) Honesty, Appraiser Assessing honesty in carrying out his duties to fulfill the agreement both for himself and for others. 4) Creativity, assessors assess the ability of employees to develop creativity to complete their work, so that they can work better. 5) Leadership, assessors assess the ability to lead, have a strong, respected, dignified personality, and can motivate others or their subordinates to work effectively. 6) The level of salary, the appraiser assesses the amount of salary that the company provides and receives the employees must be in accordance with what the employees give to the company so they are satisfied 7) Indirect compensation, the Appraiser assesses the adequate and appropriate response to employees for their contribution to help the company achieve its goals. Providing remuneration or reward for one's energy, time, thoughts and achievements given to the company. 8) Work environment, the appraiser assesses that a good work environment can make employees feel comfortable at work Appraisers assess the amount of salaries that the company provides and receives by employees must be in accordance with what employees provide to the company so that they are satisfied. 7) Indirect compensation, the Appraiser assesses the adequate and appropriate response to employees for their contribution to help the company achieve its goals. Providing remuneration or reward for one's energy, time, thoughts and achievements given to the company. 8) Work environment, the appraiser assesses that a good work environment can make employees feel comfortable at work Appraisers assess the amount of salaries that the company provides and receives by employees must be in accordance with what employees provide to the company so that they are satisfied. 7) Indirect 
compensation, the Appraiser assesses the adequate and appropriate response to employees for their contribution to help the company achieve its goals. Providing remuneration or reward for one's energy, time, thoughts and achievements given to the company. 8) Work environment, the appraiser assesses that a good work environment can make employees feel comfortable at work Providing remuneration or reward for one's energy, time, thoughts and achievements given to the company. 8) Work environment, the appraiser assesses that a good work environment can make employees feel comfortable at work Provision of remuneration or compensation for one's energy, time, thoughts and achievements given to the company. 8) Work environment, the appraiser assesses that a good work environment can make employees feel comfortable at work

\subsection{Compensation}

Sedarmayanti (2011: 239) states that compensation is everything that employees receive in return for their services. While Umar (2007: 16) states that compensation is everything that employees receive in the form of salaries, wages, incentives, bonuses, premiums, medical treatment, insurance, and other similar types that are paid directly by the company. Wibowo (2010: 461) states that compensation is a contra-performance against the use of labor or services provided by the worker. Hasibuan (2001: 54) argues that compensation is all income in the form of money, direct or indirect goods received by employees as compensation for services provided to the company.

The compensation that has been stated by Umar (2007: 16) has several indicators as follows: 1) Salary, remuneration given by the employer to employees or employees, and the recipients are routine and regular every month even though they do not come to work, the salary will still be received regularly. full. 2) Incentives, rewards or rewards given to motivate workers so that their work productivity is high, is not permanent. 3) Bonuses, paid at once for meeting performance targets. 4) Wages, payments given to employees for the length of working hours. 5) Premium, Premium is something that is given as a gift or something that is paid extra as a boost or designer or something additional payment for normal payments. 6) Treatment, Treatment in compensation is the provision of services in dealing with risks associated with employee health. 7) Insurance, insurance is a response to the risk of loss, loss of benefits and legal liability to third parties that arise from uncertain events.

\subsection{Motivation}

Work motivation is one very important aspect in determining a person's behavior, including work behavior. Every employee has different motivations or drives to work well, this is also the reason why one employee can have different work results from other employees. Kadarisman (2012: 276) states that motivation is a series of attitudes and values that influence individuals to achieve specific things in accordance with individual goals. These attitudes and values are invisble which provide strength to encourage individuals to behave in achieving goals.

According to Hasibuan (2001: 95) motivation is the provision of a driving force that creates a person's work excitement, so that they are willing to work together, work effectively and integrate with all their efforts to achieve satisfaction. Furthermore, Sulistiyani (2009: 76), namely motivation is a process of giving encouragement to subordinates so that subordinates can work in line with the limits given in order to achieve organizational goals optimally.

\subsection{Hypothesis}

Based on the objectives of the study, the phenomenon and the foundation of the theory that has been previously explained, there are three hypotheses, namely:

H1 : Motivation, and compensation have an effect on employee job satisfaction at STIE Kertanegara Malang

H2 : Motivation, Compensation and Job Satisfaction have an effect on Employee Performance at STIE Kertanegara Malang

H3 : Compensation affects employee performance at STIE Kertanegara Malang

H4 : Motivation and compensation affect employee performance through satisfaction at STIE Kertanegara Malang.

\section{METHODOLOGY}

\subsection{Population and Sampling Techniques}

Population is an area that will be studied by researchers. According to Sugiyono (2016: 271) suggests that population is an area consisting of objects or subjects that have certain qualities and characteristics that will be determined by researchers to study and then draw conclusions. The population that will be used in this research is the employees of STIE Kertanegara Malang with 30 (thirty) employees.

Sugiyono (2016: 23) states that "The sample is part of the number and characteristics of the population." In this study, the authors used a sampling technique, namely saturated sampling (Census). The definition of saturated sampling according to 
Sugiyono (2001: 61) saturated sampling is a technique of determining sampling when all members of the population are used as samples. This is often done when the total population is relatively small, less than 30 people ". In other terms saturated sampling is where all members of the population are sampled. Thus, the object in this study is all employees at STIE Kertanegara Malang, the authors took the sample in this study as many as 30 (thirty) respondents.

\subsection{Data analysis technique}

Data analysis was grouped into two, namely descriptive statistical analysis techniques and inferential statistics. Statistical descriptions are used to describe the characteristics of each variable, while inferential statistics are statistical techniques used to analyze sample data and the results are applied to the population. The structural equation model analysis in this study uses Path Analysis, which is used to determine the direct dependence relationship between a set of variables.

\section{RESEACH RESULT}

Hypothesis testing in this research aims to prove statistically about the variables that have been hypothesized based on the theory as before .. to test the hypothesis and determine the effect of intervening variables and mediate independent variables on the dependent variable and determine the Standardized value for all pathways in the structural equation model. used is multiple linear regression and path analysis.

\section{First Hypothesis Testing}

In testing the first hypothesis, namely motivation and compensation have an effect on job satisfaction at STIE Kertanegara Malang. Based on the results of testing in the regression analysis that has been carried out, the results are as in the following table:

Table 1. Hypothesis Test of Motivation and Compensation on Job Satisfaction

\section{Coefficients $^{\mathrm{a}}$}

\begin{tabular}{|c|c|c|c|c|c|c|}
\hline & \multirow[b]{2}{*}{ Model } & \multicolumn{2}{|c|}{ Unstandardized Coefficients } & \multirow{2}{*}{$\begin{array}{c}\begin{array}{c}\text { Standardized } \\
\text { Coefficients }\end{array} \\
\text { Beta }\end{array}$} & \multirow[b]{2}{*}{$\mathbf{t}$} & \multirow[b]{2}{*}{ Sig. } \\
\hline & & $\mathbf{B}$ & Std. Error & & & \\
\hline \multirow[t]{3}{*}{1} & (Constant) & 5.762 & 7.305 & & 7.158 & .000 \\
\hline & Motivaton & .297 & .239 & .384 & 3.404 & .001 \\
\hline & Compensation & .374 & .228 & .424 & 5.521 & .000 \\
\hline
\end{tabular}

a. Dependent Variable: Job Satisfaction

Data source :output is processed SPSS data 16.

Based on the table above, it can be seen in the Standardized Coefficient $(\beta)$ Column in the regression analysis, the value $(\beta)$ of the motivation variable is 0.384 and the $t$ value is 3.404, while for the $t$ table value is 2.051 , so when compared between $t$ and $t$ The table is 3.404> 2,051 with a significant value of $0.001<0.05$ means that motivation has a significant effect on job satisfaction, while the compensation variable can be seen that the value $(\beta)$ is 0.424 and the $t$ value is 5,521>2,051 with a significant value of $0,000<0,05$ which means that compensation has a significant effect on job satisfaction. Thus, the first hypothesis can be concluded that the motivation and compensation variables have a significant effect on job satisfaction at STIE Kertanegara Malang, this is acceptable and correct.

\section{Second Hypothesis Testing}

In the second hypothesis, motivation and compensation have an effect on employee performance at STIE Kertanegara Malang. Based on linear regression testing, the following results are obtained: 
International Journal of Research in Social Science and Humanities (IJRSS), Vol. 2, No. 3, May - 2021

Table 2. Second Hypothesis

Coefficients $^{\mathrm{a}}$

\begin{tabular}{|c|c|c|c|c|c|c|}
\hline & \multirow{2}{*}{ Model } & \multicolumn{2}{|c|}{ Unstandardized Coefficients } & \multirow{2}{*}{$\begin{array}{c}\begin{array}{c}\text { Standardized } \\
\text { Coefficients }\end{array} \\
\text { Beta }\end{array}$} & \multirow{2}{*}{$\mathbf{t}$} & \multirow{2}{*}{ Sig. } \\
\hline & & B & Std. Error & & & \\
\hline \multirow[t]{3}{*}{1} & (Constant) & 16.905 & 4.614 & & 3.664 & .001 \\
\hline & Motivaton & .329 & .151 & .404 & 4.121 & .004 \\
\hline & Compensation & 221 & .144 & .287 & 3.539 & .002 \\
\hline
\end{tabular}

a. Dependent Variable: Employee Performance

Data source :output is processed SPSS data 16.

Based on the table above, it can be seen in the Standardized Coefficients column the value $(\beta)$ of the motivation variable is 0.404 and the $t$ value is 4.121 , so when compared with the $t$ table value, it is $4.121>2,051$ with a significant value of $0.004<0.05$ and when viewed in the results of the compensation variable, the value $(\beta)$ is obtained of 0.287 and the $t$ value of 3.539 , when compared with the $\mathrm{t}$ table value, 3.539> 2,051 with a significant value of $0.002<0.05$, which means that motivation and compensation have a significant effect on employee performance.

Thus, the second hypothesis can be concluded that the motivation and compensation variables have a significant effect on employee performance at STIE Kertanegara Malang and this can be accepted is proven correct.

\section{Third Hypothesis Testing}

In testing the third hypothesis, namely job satisfaction on employee performance at STIE Kertanegara Malang. Based on the results of linear regression, the following results are obtained:

Table 3. Third Hypothesis

\begin{tabular}{|c|c|c|c|c|c|c|}
\hline & \multirow{2}{*}{ Model } & \multicolumn{2}{|c|}{ Unstandardized Coefficients } & \multirow{2}{*}{$\begin{array}{c}\begin{array}{c}\text { Standardized } \\
\text { Coefficients }\end{array} \\
\text { Beta }\end{array}$} & \multirow{2}{*}{$\mathbf{t}$} & \multirow{2}{*}{ Sig. } \\
\hline & & B & Std. Error & & & \\
\hline \multirow[t]{2}{*}{1} & (Constant) & 30.792 & 4.241 & & 7.260 & .000 \\
\hline & Job Satisfaction & .150 & .130 & .418 & 4.104 & .000 \\
\hline
\end{tabular}

a. Dependent Variable: Employee Performance

Data source :output is processed SPSS data 16.

Based on table 3 above, it can be seen in the Standardized Coefficients column the value $(\beta)$ of the Job Satisfaction variable is 0.418 and the $t$ value is 4.104 , so when compared with the $t$ table value, namely $4.104>2.051$ with a significant value of 0.000 $<0.05$, which means that job satisfaction has a significant effect on employee performance. Thus, the second hypothesis can be concluded that the Satisfaction variable has a significant effect on employee performance at STIE Kertanegara Malang and this can be accepted proven to be correct.

\section{Fourth Hypothesis Testing}

In testing the fourth hypothesis, namely motivation and compensation have an effect on employee performance through job satisfaction at STIE Kertanegara Malang. Based on the results of linear regression, the following results are obtained: 
Table 4. Fourth Hypothesis

\begin{tabular}{|c|c|c|c|c|c|}
\hline $\begin{array}{c}\text { Independent } \\
\text { Variable }\end{array}$ & $\begin{array}{c}\text { Intervening } \\
\text { Variables }\end{array}$ & Dependent Variable & Direct Influence & $\begin{array}{c}\text { Total Indirect } \\
\text { Effect }\end{array}$ & Result \\
\hline Motivation & & Performance & 0.404 & & \\
\hline Compensation & & Performance & 0.296 & & \\
\hline Motivation & Job satisfaction & Performance & & 0.564 & $0.404<0.564$ \\
\hline Compensation & Job satisfaction & Performance & & 0.473 & $0.296<0.473$ \\
\hline
\end{tabular}

Source: Primary data processed.

Based on table 4 above, it can be seen that the direct effect of the motivation variable on employee performance is 0.404 , while the indirect effect of the motivation variable on employee performance through job satisfaction is 0.160 , so the total indirect effect between the motivation variable on the employee performance variable amounting to 0.564. Based on the results of the calculations in table 22 above, it can be concluded that the total value of the indirect effect is $0.564>0.404$ compared to the direct effect. So in this case it shows that motivation indirectly affects employee performance through job satisfaction.

In the compensation variable on employee performance, the direct effect is 0.296, while the indirect effect on the compensation variable on employee performance is 0.177 , the total indirect effect is 0.473 . Based on the results of the above calculations, it can be concluded that the total value of the indirect effect is $0.473>0.296$, this indicates that indirectly compensation affects employee performance through job satisfaction.

In this test, it shows that Job Satisfaction has mediated between Motivation and Compensation on employee performance, thus the fourth hypothesis in this study, namely Motivation and Compensation has a significant effect on performance through job satisfaction at STIE Kertanegara Malang can be accepted and proven correct.

\section{DISCUSSION}

\subsection{Effect of Motivation and Compensation on Job Satisfaction at STIE Kertanegara Malang}

Motivation has an effect on job satisfaction, this shows that employee job satisfaction will be created with good motivation which consists of 3 indicators, namely Existence, Relatedness, Growth Needs (growth), besides compensation is reflected by the presence of 3 indicators which include salary, Incentives, and bonuses. If the motivation given is in accordance with the employee's expectations, then the employee will be able to work well besides that the employee will feel satisfied in completing the task that has been given to the employee. And vice versa, if motivation cannot be created properly and does not meet employee expectations, employees will be disappointed and they will feel dissatisfied at work. The higher the motivation given to employees, the employees will feel satisfied at work. In addition, there is also the effect of compensation on job satisfaction at STIE Kertanegara Malang. With good compensation and according to employee expectations, employee job satisfaction will be created well too, and vice versa if compensation cannot be provided properly and appropriately by the agency, employees will not be satisfied at work.

The results of this study support the results of research supporting Maryam Al-Sada (2017) who examines the influence of organizational culture and leadership style on employee satisfaction, commitment and motivation in the education sector in Qatar. Which states that there is a relationship and motivation influence between motivation and job satisfaction.

Research supports the results of research by Sukidi and Farid (2016) regarding the effect of motivation, compensation and job satisfaction on employee performance with job satisfaction as an intervening variable which concludes that motivation has an effect on job satisfaction, besides compensation also has a significant effect on job satisfaction. The results of this study also support the results of research from Ni Made Nurcahyani (2016) regarding the effect of compensation and motivation on employee performance with job satisfaction as an intervening variable which concludes that motivation and compensation have an effect on job satisfaction. With good motivation and compensation, it will be able to create employee job satisfaction in working at the agency. This agrees with Hasibuan (2001: 95) that giving motivation is a driving force that creates a person's work enthusiasm with all his efforts to achieve satisfaction at work, besides being in line with opinion Handoko (2008: 114-118) which states that with compensation it will be possible improve work performance, motivation and job satisfaction and can improve their life needs 
properly.

\subsection{The Influence of Motivation and Compensation on Employee Performance at STIE Kertanegara Malang}

Motivation and compensation have an effect on employee performance at STIE Kertanegara Malang, which means that with good motivation and compensation in accordance with employee expectations, it can create employee performance well in completing work and can achieve company goals well. This study is in line with the results of research by Sukidi and Farid (2016) on the effect of motivation, compensation, and job satisfaction on employee performance with job satisfaction as an intervening variable, the results of this study indicate that motivation has a significant effect on employee performance. In addition, the results of this study also support the results of Ni Made Nurcahyani's research (2016) which states that there is a good motivation influence on employee performance.

The results of this study support the results of research conducted by Bilal Jamil (2011) on the Impact of Compensation, Performance Evaluation, and Promotion Practices on Government Employees Performance vs Private Employees (Impact of Compensation, Performance Evaluation and Promotion Practices on Government Employees Performance VS Private Employees Performance). .) in this study states that compensation has an influence on employee performance.

The higher the motivation and compensation, the better the employee, the higher and the better the employee's performance. An employee will have a good performance if he has desires, hopes, goals, goals, encouragement and incentives that are supported by good work abilities. So that by motivating employees and providing good compensation, and increasing work ability, it can improve employee performance, besides that, so that employees are able to maintain and continue to exist in an era of strong competition, appropriate and good motivation and compensation will increase and foster employee morale so that thus achieving good employee performance. Thus, the results of this study can be concluded that motivation and compensation have a significant effect on employee performance at STIE Kertanegara Malang.

\subsection{Effect of Job Satisfaction on Employee Performance}

Job satisfaction affects employee performance. This means that an increase in job satisfaction can improve employee performance properly. Job satisfaction is one of the factors that has the most important role in employee performance. With good job satisfaction at work it will greatly affect employee performance.

The results of this study are supported by the results of research reinforced by the results of research conducted by Mutia Arda (2017) concerning the Effect of Job Satisfaction and Work Discipline on Employee Performance at Bank Rakyat Indonesia, Putri Hijau Branch, Medan, which states that the effect of job satisfaction on performance. The results of this study are in line with the results of Rezkiawan (2016) research on The Role of Job Motivation and Job Satisfaction in Mediating The Effect of Teacher's Certification on The Teacher's Performance in Gorontalo Elementary (The Role of Work Motivation and Job Satisfaction in Mediating the Effect of Teacher Certification on Teacher Performance in Gorontalo) which states that there is an influence on compensation on employee performance.

\subsection{Effect of Motivation and Compensation on Employee Performance through Job Satisfaction}

The influence of motivation and compensation on employee performance through job satisfaction has a very important role in a company, this will be very beneficial for the company in order to achieve company goals well. If seen from the results of the fourth hypothesis, it shows that there is a direct influence on the motivation variable on employee performance, and there is also an indirect effect on the motivation variable on employee performance through job satisfaction. This is indicated by the comparison between the total indirect effect and the direct effect on the motivation variable on employee performance.

Furthermore, there is the same thing as motivation, namely there is a direct influence on the compensation variable on employee performance, and there is also an indirect effect on compensation on employee performance through job satisfaction. So in this case we also get a comparison between the total indirect effect and the direct effect on the compensation variable on employee performance, which is equal to 0.473>0.296, so the results above indicate that Job Satisfaction has mediated between Motivation and Compensation on employee performance, thus conclusions can be drawn. that in this study, motivation and compensation have a significant effect on performance through job satisfaction at STIE Kertanegara Malang. 


\section{CONCLUSION}

Based on the results of the research and discussion that has been described, the results obtained are as follows:

a. The results of the description show that motivation is formed by several indicators, namely including existence, connection, and growth. The main thing that can increase motivation is existence, which is where employees feel that needs such as a place to live and clothing can be fulfilled properly in their work, while Growth is where employees feel that the ideas and suggestions that are given for the progress of the institution make them excited to work. The description of compensation is formed with several indicators including salary, incentives, and bonuses, in the description of job satisfaction there are several indicators, namely ability, honesty and environment, besides that in the performance description there are several indicators which include quality, quantity and responsibility.

b. The influence of motivation and compensation on employee job satisfaction at STIE Kertanegara Malang, namely that motivation has an influence on job satisfaction at STIE Kertanegara Malang, this means that the higher the motivation of employees to the agency, it will encourage employees to get good work performance. And besides that compensation has a significant influence on job satisfaction. This means that the more compensation is in accordance with what has been given according to life, the employee job satisfaction in working at STIE Kertanegara will increase. So in this study it can be concluded that motivation and compensation for job satisfaction have a significant effect.

c. The Influence of Motivation, Compensation, and Job Satisfaction on Employee Performance. From the results of the discussion on the previous page, it can be concluded that there is a significant influence between Motivation, Compensation, and Job Satisfaction on employee performance at STIE Kertanegara Malang, this is evidenced by the research results, namely that motivation has a significant effect on employee performance, so from these results It can be concluded that the higher the motivation of employees, the more they will encourage employees to always work and complete the tasks given by the agency or company properly. Compensation has a significant effect on employee performance, this means that the more appropriate the compensation given to employees according to their needs, it will improve and achieve good performance for employees, besides that it can also be seen from the previous discussion that job satisfaction also has a significant effect on employee performance. Which means that high job satisfaction will increase good performance at STIE Kertanegara Malang.

d. From the results of research conducted by researchers, the variable job satisfaction has a role as a variable that mediates between the influence of the motivation and compensation variables on employee performance. The mediating role of the job satisfaction variable in this study is to be able to increase the value of the influence between the independent and dependent variables in this study.

\section{SUGGESTION}

Based on the results of research conducted on employees of STIE Kertanegara Malang, there are several suggestions for agencies and for further research. Suggestions that can be conveyed by researchers are as follows:

a. STIE Kertanegara Malang needs to provide compensation in accordance with the results of the work that the employees have given to the company, because by giving appropriate compensation will increase the sense of job satisfaction towards employees.

b. It is suggested to STIE Kertanegara Malang to pay more attention to motivation and compensation, so that employees feel satisfied working at STIE Kertanegara Malang so that the work results are in accordance with the expectations of the institution.

c. Future researchers are advised to research other educational institutions that may experience the same problems as this research.

d. For future research it is recommended to add other independent variables besides motivation and compensation which of course can affect the dependent variable of employee performance, or can add more recent territorial sources in order to complement this research.

\section{REFERENCES}

Gibson, James, L.,2000, Organization, Behavior, Structure and Process, 5th Edition. 3rd printing. Jakarta: Erlangga Publisher. 
Greenberg, Jerald and Robert Baron (2003), Behavior in Organizations (understanding and managing the human side of work). Eight edition, Prentice Hall.

Handoko, T. Hani, 2008. Human Resources Management, Second Edition, Yogyakarta, Publisher: BPFE.

Hasibuan, Malayu. 2001. Human Resource Management: Basic Definition, Understanding, and Problems. Jakarta: PT. Gunung Agung Shop

Kadarisman, 2012, Human Resource Development Management, Jakarta: Raja Grafindo Persada.

Mangkunegara, Anwar Prabu, 2016, Company Human Resource Management, 2nd Printing, PT. Youth Rosda Karya, Bandung.

Maryam Al-sada. 2017. Influence of organizational culture and leadership style on employee satisfaction, commitment and motivation in the educational sector in Qatar. Euromed Journal of Business, Volume 12 (2): 163-188.

Mutia Arda. 2017. The Effect of Job Satisfaction and Work Discipline on Employee Performance at Bank Rakyat Indonesia, Putri Hijau Branch, Medan. Management \& Business Scientific Journal, Vol 18 No1 PP 45-60

Ni Made, Nur Chayani. 2016. The effect of compensation and motivation on employee performance with job satisfaction as an intervening variable

Notoatmodjo, Soekidjo. 2009. Human Resource Development. Jakarta: Rineka Cipta.

Rezkiawan, Tantawi. 2016. The Role of Job Motivation and Job Satisfaction in Mediating the Effect of Teacher's Certification on The Teacher's Performance in Gorontalo Elementary School. Journal of Management Applications (JAM), Vol 14 No 4

Robbins, Stephen P. 2003 Organizational Behavior Index Jakarta.

Sedarmayanti 2011 Human Resource Management, Bureaucratic Reform and Civil Servant Management (fifth printing) Bandung: PT RefikaAditama

Sopiah. 2008. Organizational Behavior, Yogyakarta: Andi Offset.

Sugiyono 2016. Quantitative Research Methods, Qualitative and R \& D. Bandung: PT Alphabet.

Sukidi \& Wajdi, F. 2016 The effect of motivation, compensation, and job satisfaction on employee performance with job satisfaction as an intervening variable. Competitiveness Journal of Resource Management Economics, 18 (2), 13

Sulistiyani, Teguh Ambar, and Rosidah, 2009, Human Resource Management. Yogyakarta: Grahallmu.

Umar Husein. 2007, Research Methods for Thesis and Business Thesis, Jakarta: PT. Raja Grafindo Persada.

Rivai, Veithzal. 2004, Human Resource Management for Companies, First Edition, Jakarta, PT. Raja Grafindo Persada,

Wibowo 2010. Performance Management. Jakarta: Rajawali Press 